\title{
ANTIMICROBIAL ACTIVITY AND PHYSICAL PROPERTIES OF CHITOSAN-AREN SEED (Arenga Pinnata) STARCH EDIBLE FILM
}

\author{
A. Candra ${ }^{\bowtie}$, J. Kaban and M. Ginting \\ Department of Chemistry, Faculty of Mathematics and Natural Sciences, Universitas Sumatera \\ Utara, Medan, Indonesia, 20155. \\ Corresponding Author: andch3n@usu.ac.id
}

\begin{abstract}
This study investigated the antimicrobial activity and physical properties of film membrane based on chitosan - aren seed starch $1: 2(\mathrm{w} / \mathrm{w})$ on the quality of refrigerated salmon fillets. The scope of this study was physical properties, characterization of the films, and the effect of the film-coated on salmon fillets. Different biological assays were used to analyze the film's total psychrophilic and mesophilic bacteria, inhibition zone, and biodegradation. The results of this study showed that gram-positive bacteria acquired a higher inhibition zone index than gram-negative bacteria. Salmon fillets that were applied to the film had adequate total count bacteria through Indonesia National Standard of Food Packaging during storage at $5^{\circ} \mathrm{C}-10^{\circ} \mathrm{C}$ until 5 days $\left(10^{5}\right.$ organisms $\left./ \mathrm{g}\right)$ but inadmissible for the noncoated salmon fillets as a control. This edible film can maintain the shelf life of seafood products such as salmon fillets which could lower the respiration activity compare to noncoated assays. Also, biodegradation activity against Aspergillus niger showed destruction to the film that indicated the film was biopolymer and could be decomposed. The film has good transparency, water vapor transmission rate of the blended film $\left(6.3844 \mathrm{~g} / \mathrm{m}^{2} / \mathrm{h}\right)$, elongation at break $(15.94 \%)$, Tensile Strength $(0.308 \mathrm{MPa})$, and the water activity was below the threshold for microbial growth. The film showed a strong intermolecular hydrogen bond which could be proved by FT-IR analysis and smooth surface by Scanning Electron Microscope. Thus, the blended film based on chitosan and aren-seed starch was beneficial for food packaging.
\end{abstract}

Keywords: Chitosan, Aren-seed Starch, Antimicrobial Film, Mechanical and Physical Properties.

RASĀYAN J. Chem., Vol. 14, No.3, 2021

\section{INTRODUCTION}

The expansion of elastic food packaging can reduce the microbial activity of food products; however, environmental problems are a huge issue for the overuse of synthetic materials. Therefore, there is increased concerns about the study of seafood packaging industries based on biodegradable materials. ${ }^{1}$ Chitosan (CT) is obtained by partial deacetylation of chitin, which is a straight-chain polysaccharide that comprises $\beta$-(14)-2-acetamido-D-glucose and $\beta$-(1-4)-2-amino-D-glucose, CT has many unique properties that can be applied in the food industry and "generally recognized as safe" (GRAS) dignity for consumption. CT has favorable advantageous properties as emulsifiers and preservatives for food coatings, biotechnology, medicine as a drug delivery system and the pharmaceutical industry. ${ }^{2}$ Antimicrobial activity of CT is determined by the degree of deacetylation, $\mathrm{pH}$, molecular weight, scattering of the deacetylated group through the polymer chain, the ionic cohesion in the medium and the correlated counter ions of the salts. ${ }^{3}$ CT biofilms contain high water vapor permeability (WVP) and display low moisture content and oxygen permeability. ${ }^{4}$ Edible films production based on macromolecules mainly consists of polysaccharides and proteins. The mechanical properties (strengths and/or weaknesses) produce enthusiasm for developing blended edible films and coatings that can be formed by mixing two or more macromolecules such as chitosan and different kind of starches. ${ }^{5}$ Common synthetic plastics have many consequences for the environment, thus biodegradable materials such as cellulose, gums, starches, or proteins are used for biofilm production massively. ${ }^{6}$

Enau or Kabung is commonly named for the sugar palm tree. Relatively there are 150 names of it in Malaysia and Indonesia. ${ }^{7}$ Sugar Palm Tree can be found in the region among South Asia to South East Asia 
(Indonesia, Vietnam, Philippine, Thailand, Myanmar), Taiwan, Australia and Papua New Guinea. Equatorial countries such as Indonesia, Thailand and Malaysia are central to various categories of innate fiber and the specific one is aren palm (Arenga pinnata) fiber. ${ }^{8}$ Blending of two biopolymers had been researched to form edible films such as film based on chitosan-cassava starch that increases their physical and mechanical properties in tensile modulus and tensile strength, however, there is a reduction in elongation ratio of the film. ${ }^{9}$

Salmon contains omega-3 fatty acids and various kinds of polyunsaturated fatty acids. Thus, it is considered a high-quality fat fish. Most of the fresh salmon are peddled as fillets or whole fish to the consumers. Since the interest in fresh salmon fishes is high, researchers tend to find advanced methods and technologies to preserve the fish. One of the possible methods is using edible coating or edible film to preserve the fresh fishes from microbial growth. ${ }^{10}$ Coated and uncoated cold-smoked sardine with chitosan and the gelatinbased edible film had been reported that lowering the microbial growth under high pressure and refrigeration. ${ }^{11}$ Antimicrobial activity of tapioca starch - chitosan-based edible coatings on salmon muscles had been reported that chitosan with its mechanical, physical and antimicrobial properties had a huge effect on the quality of salmon fillets. ${ }^{12}$ Chitosan edible film that enhanced with essential oil of Pimpinella anisum $L$ can prolong the quality of chicken burger had proved against some pathogenic microbes such as Pseudomonas aeruginosa, Staphylococcus aureus and Escherichia coli. ${ }^{13}$

According to the above statements, this study aimed to evaluate the antimicrobial activity against grampositive and gram-negative bacteria, the outcome of the film when applied to salmon fillet for food packaging, the structural and characterization of Chitosan-Aren Seed Starch (CTASS) were investigated by FT-IR, SEM, tensile strength, water vapor transmission rate and their respiration rate for $\mathrm{O}_{2}$ and $\mathrm{CO}_{2}$.

\section{Material and Methods}

\section{EXPERIMENTAL}

All materials needed in this research, namely $\mathrm{CH}_{3} \mathrm{COOH}$, glycerol, $\mathrm{K}_{2} \mathrm{SO}_{4}, \mathrm{~K}_{2} \mathrm{Cr}_{2} \mathrm{O}_{7}$, chitosan of high molecular weight $(>75 \%)$ are derived from Sigma Aldrich without further purification. Commercial aren seed was obtained from local products in Tebing-Tinggi, North Sumatra, Indonesia. The bacterial strain Staphylococcus aureus (gram-positive bacteria), Shigella, Escherichia coli, Salmonella and Pseudomonas aeruginosa (gram-negative bacteria) was gained from the Microbiology Laboratory, Faculty of Mathematics and Natural Sciences, Universitas Sumatera Utara.

\section{Preparation of Aren Seed Starch (ASS) Solution}

Sugar palm fruits were boiled and broke into flesh. The fleshes were washed with water and soaked in lime water for 2-3 days. After soaking, the fleshes were mashed up, dried in a vacuum oven at $35^{\circ} \mathrm{C}, 50 \mathrm{~cm} \mathrm{Hg}$ and the dried samples were weighed. $2 \%(\mathrm{w} / \mathrm{w}$ ) of ASS was dissolved in $100 \mathrm{ml}$ of water-glycerol 0,64\% $(\mathrm{w} / \mathrm{w})$ suspensions. The dispersions were heated at $70^{\circ} \mathrm{C}$ on a hotplate for $30 \mathrm{~min}$ under continuous stirring to gelatinize starch effectively.

\section{Preparation of Chitosan-Aren Seed Starch (CTASS) Solution}

Chitosan of high molecular weight $(>75 \%)$ was dispersed in acetic acid $1 \%(\mathrm{w} / \mathrm{w})$ under stirring using a magnetic stirrer and $100 \mathrm{ml}$ of glycerol $0.64 \%(\mathrm{w} / \mathrm{w})$ was added to prepare solutions of proper concentrations. The film was made by mixing gelatinized ASS/glycerol with chitosan dispersion. Moreover, it was allowed under vacuum conditions to remove air and continuous stirring to the blend solutions.

\section{Edible Film Preparation}

The casting technique was applied to form edible film: $20 \mathrm{~g}$ of film blending solutions were poured on 9 $\mathrm{cm}$ diameter Petri dishes and dehydrated in a desiccator for $48 \mathrm{~h}$. Inside desiccator containing silica gel which provided approximately $58 \%$ of humidity for $48 \mathrm{~h}$ at $25^{\circ} \mathrm{C}$, before testing.

\section{Antimicrobial Barrier Assay}

Antimicrobial activity was performed by a zone of inhibition using Staphylococcus aureus (gram-positive bacteria), Salmonella, Shigella, Pseudomonas aeruginosa and Escherichia coli (gram-negative bacteria). 
The colonies were diluted using $\mathrm{NaCl} 0.92 \%(\mathrm{w} / \mathrm{w})$ and their turbidity was compared with $10^{8} \mathrm{McFarland}$ standard solution. Performing the assay by casting $100 \mu \mathrm{l}$ of each inoculum of colonies to $10 \mathrm{ml}$ of restrained Mueller Hinton Agar which were poured into petri dish respectively. Then, $0.52 \mathrm{~cm}$ diameter of the edible film was aseptically cut and place on the firm agar. The petri dishes were evaluated for clear zones around film after $24 \mathrm{~h}$ incubation at $37^{\circ} \mathrm{C}$. The diameter of the inhibition zone was assessed in triplicate and the means were calculated.

\section{Salmon Fillet Coating Assay}

The fillets were cut $(10 \mathrm{~g})$ and then wrapped with CTASS film, and without films as a control. The samples were kept in a refrigerator and stored at $5-10^{\circ} \mathrm{C}$ for 20 days. For analysis, $1 \mathrm{~g}$ of salmon fillets were cut aseptically and incorporated with $10 \mathrm{ml}$ sterile distilled water and homogenized. The culture was diluted $10^{4} \mathrm{CFU} / \mathrm{ml}$, and $100 \mu \mathrm{l}$ of the culture and $10 \mathrm{ml} \mathrm{PCA} \mathrm{(Plate} \mathrm{Count} \mathrm{Agar} \mathrm{)} \mathrm{were} \mathrm{homogenized} \mathrm{and} \mathrm{poured}$ into $9 \mathrm{~cm}$ diameter petri dish, and the total psychrophilic and mesophilic bacteria were reviewed in PCA after incubation at $37^{\circ} \mathrm{C}$ for 24 hours at selected days $(0,1,2,3,5,10,15$ and 20$)$ days, respectively.

\section{Biodegradation Assay}

CTASS film $\left(3 \times 3 \mathrm{~cm}^{2}\right)$ was aseptically transferred into ethanol solution $70 \%(\mathrm{v} / \mathrm{v})$ and sterilized distilled water for 5 minutes, respectively. The film was placed on the surface of the culture medium that has been inoculated with the Aspergillus niger and films in the culture medium were incubated at $29^{\circ} \mathrm{C}$ for 24 hours at selected days $(0,3,6,9,12,15,18$ and 21 days $)$, the loss of the mass was evaluated. The biodegradable film on $21^{\text {th }}$ day was analyzed with FT - IR and the morphology of the surface was tested by SEM.

\section{Film Thickness Measurement}

The thickness of the sample was evaluated with a digital micrometer screw. The thickness of the films was evaluated triplicated at five points of the sample.

\section{Water Activity Analysis}

Using graphical interpolation method of Landrock and Proctor with slight modification. ${ }^{14}$ Films are placed in a humidity chamber for 24 hours (curbed by saturated salt solutions: $\mathrm{K}_{2} \mathrm{SO}_{4}, \mathrm{~K}_{2} \mathrm{Cr}_{2} \mathrm{O}_{7}$ and silica gel) and achieved equilibrium. The relative humidity is plotted against the diversity of weight loss or weight gain and convert into $\mathrm{a}_{\mathrm{w}}$ by interpolation graph.

\section{Water Vapor Transmission Rate (WVTR), Tensile Strength (TS) and Elongation at Break (\%E) of CTASS Films}

To carry out this experiment, ASTM No. E96/E96M-05 was used..$^{15}$ Edible Films were conditioned before testing for WVP. Films were put into a humidity chamber that containing silica gel. TS and $\% \mathrm{E}$ were measured using Universal Testing Machine (HUNG TA, TH-8503). The film was cleavaged in rectangles of $9 \times 1 \mathrm{~cm}$ and the speed of the jaw is $30 \mathrm{~mm} / \mathrm{min}$ with $5 \mathrm{~cm}$ distance between the jaws based on D882-91 ASTM method.

\section{Scanning Electron Microscope}

The surface and the cross-section of CTASS film were characterized by a scanning electron microscope (JEOL JSM 6360LA). Films were examined at magnifications between 2000x to 5000x of their initial size.

\section{FT - IR Analysis}

FT-IR spectra of chitosan, ASS, CTASS, and biodegradation of the film were recorded using spectrometer Shimadzu Prestige-21 at wave number $4000-5000 \mathrm{~cm}^{-1}$.

\section{Respiration Rate of $\mathrm{O}_{2}(\mathrm{~g})$ and $\mathrm{CO}_{2}(\mathrm{~g})$}

The respiration activity of the salmon slice coated and noncoated was analyzed by $\mathrm{O}_{2}$ and $\mathrm{CO}_{2}$ cosmotector. ${ }^{16}$ The rate of respiration can be calculated by: 
$R_{r}=\frac{10^{3} \times M_{r} \times \frac{\Delta C}{100} \times\left(V-\frac{W}{\sigma}\right)}{R \times W X \operatorname{ta}\left(273+t_{0}\right)}$

Where:

$\mathrm{R}_{\mathrm{r}} \quad=$ Rate of Production of $\mathrm{CO}_{2}(\mathrm{ml} / \mathrm{kg} . \mathrm{hr})$

$\mathrm{M}_{\mathrm{w}} \quad=$ Molecular weight

$\Delta C=$ Different in Concentration of $\mathrm{O}_{2}$ and $\mathrm{CO}_{2}$

$\mathrm{V} \quad=$ Volume of container

$\mathrm{R}=$ Ideal Gas Constant (0.0821 L.atm. $\left.\mathrm{mol}^{-1} \mathrm{~K}^{-1}\right)$

Inhibition Zone of Antimicrobial Assay

The inhibition zone was measured with calipers.

\section{RESULTS AND DISCUSSION}

\section{Characteristic and Mechanical Properties Analysis}

CTASS 1: $2(\mathrm{w} / \mathrm{w})$ coating film with $0.64 \%(\mathrm{w} / \mathrm{w})$ glycerol showed well-being flexibility as shown in Fig.1 .

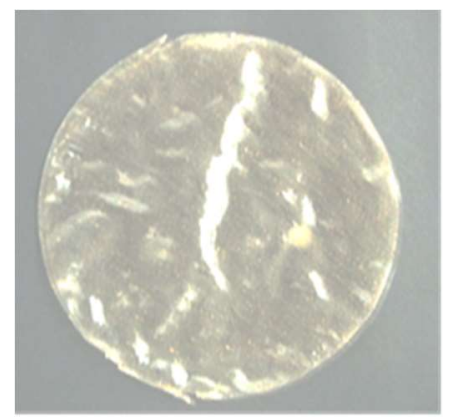

Fig.-1: A Translucent CTASS Film with $0.64 \%$ (w/w) Glycerol as Plasticizer

Naturally, the essential factor in film making is thickness, which precisely influences the microbial characteristics and endurance of the packaging products. According to this study, the thickness of the sample is $0.090 \mathrm{~mm}$ which is measured by a micrometer screw at five different points of the sample. Compared with Chitosan - tapioca starch edible film by Vasconez et al. ${ }^{12}$ with ratio 1:2 (w/w) and $0.64 \%$ $(\mathrm{w} / \mathrm{w})$ glycerol as plasticizer obtained the film thickness was $0.197 \pm 0.012 \mathrm{~mm}$. CTASS film is thinner than Chitosan - tapioca starch film but this was not a definitive measure since one of the factors for casting technique depends on the drying status and the amount of biopolymer solution used.

Water activity is one of the hydration parameters which was often interpreted as the water content in specimens that could be used for the growth of microorganisms. From Table-1, the water activity of CTASS film was still below the threshold for microbial growth which is equal to 0.486 , where most microbes (especially bacteria) grow well in foodstuffs that had $\mathrm{a}_{\mathrm{w}}$ around $0.9-0.97$; yeast requires $\mathrm{a}_{\mathrm{w}} 0.87-0.91$ and mold requires $\mathrm{a}_{\mathrm{w}} 0.8-0.91 .{ }^{17}$

Table-1: Water Activity of CTASS Film with Different Salts Solutions and Silica Gel

\begin{tabular}{c|c}
\hline Salt Solution / Silica & Water Activity $\left(\mathrm{a}_{\mathrm{w}}\right)$ \\
\hline $\mathrm{K}_{2} \mathrm{SO}_{4}$ & 0.513 \\
\hline $\mathrm{K}_{2} \mathrm{Cr}_{2} \mathrm{O}_{7}$ & 0.516 \\
\hline Silica Gel & 0.430 \\
\hline Average & 0.486 \\
\hline
\end{tabular}

Interpretation of the rate of WVP of biopolymer films is needed if antimicrobial films are used in food packaging with high humidity. Polymers with high polarity (polysaccharides and proteins) generally produce high WVP values. Since the polymer has a large hydrogen bond that is not effective in holding water vapor. ${ }^{18}$ According to Vasconez et al. ${ }^{12}$ films obtained from chitosan showed lower WVP than tapioca starch films. This is due to strong interactions of hydroxyl group between tapioca starch and chitosan 
RASĀYAN J. Chem.

Vol. 14 | No. 3 |1860-1868| July - September | 2021

decrease the interaction with water molecules since hydrophilic groups of starch is blocked by functional groups in chitosan. According to Givianna et al. ${ }^{19}$ Chitosan based edible films have a lower water vapor transmission rate which has a better limit for absorbing water vapor than edible films that are made from other biopolymers (casein, alginate, etc). The addition of chitosan to ASS matrix is believed to reduce the WVP rate, which is a quite low transmission rate of $6.3844 \mathrm{~g} / \mathrm{m}^{2} / \mathrm{h}$.

The tensile strength and elongation break are one of the ultimate mechanical properties of a film that should be considered for food packaging. The tensile strength can be tested over the peak stress needed to damage the film all along with analysis. ${ }^{20}$ Plasticizer which is added to blended film influences the tensile strength which results in increased flexibility since less hydrogen bond occurs in the blended film. Using a plasticizer such as glycerol will reduce the tensile strength of the film. ${ }^{21,22,23}$

The film has an elongation at break (15.94\%) and maximum tensile strength (0.308 MPa) which measured triplicate. This film indicated a high elongation break which is good for packaging material but furthermore, their low tensile strength should be investigated.

The respiration rate of the film was measured by the changes in the concentration of $\mathrm{O}_{2}$ and $\mathrm{CO}_{2}$ gas at $10^{\circ} \mathrm{C}$ based on a certain time interval (hours). From the observations, it was found that the concentrations of $\mathrm{O}_{2}$ and $\mathrm{CO}_{2}$ at $10^{\circ} \mathrm{C}$ for coated salmon had a lower rate than non-coated salmon. In this case, a CTASS film applied on the salmon fillet had an acceptable average respiration rate $\left(73.072 \mathrm{ml} / \mathrm{kg} . \mathrm{h}\right.$ for $\mathrm{O}_{2}$ and $58.293 \mathrm{ml} / \mathrm{kg}$.h for $\mathrm{CO}_{2}$ ). In contrast, the noncoated salmon fillets have a steady increase in respiration rate ( $74.711 \mathrm{ml} / \mathrm{kg} . \mathrm{h}$ for $\mathrm{O}_{2}$ and $73.982 \mathrm{ml} / \mathrm{kg}$.h for $\mathrm{CO}_{2}$ ) that indicated this film which is applied to salmon fillets can maintain the shelf life of seafood product, especially salmon fillets (Fig.-2).

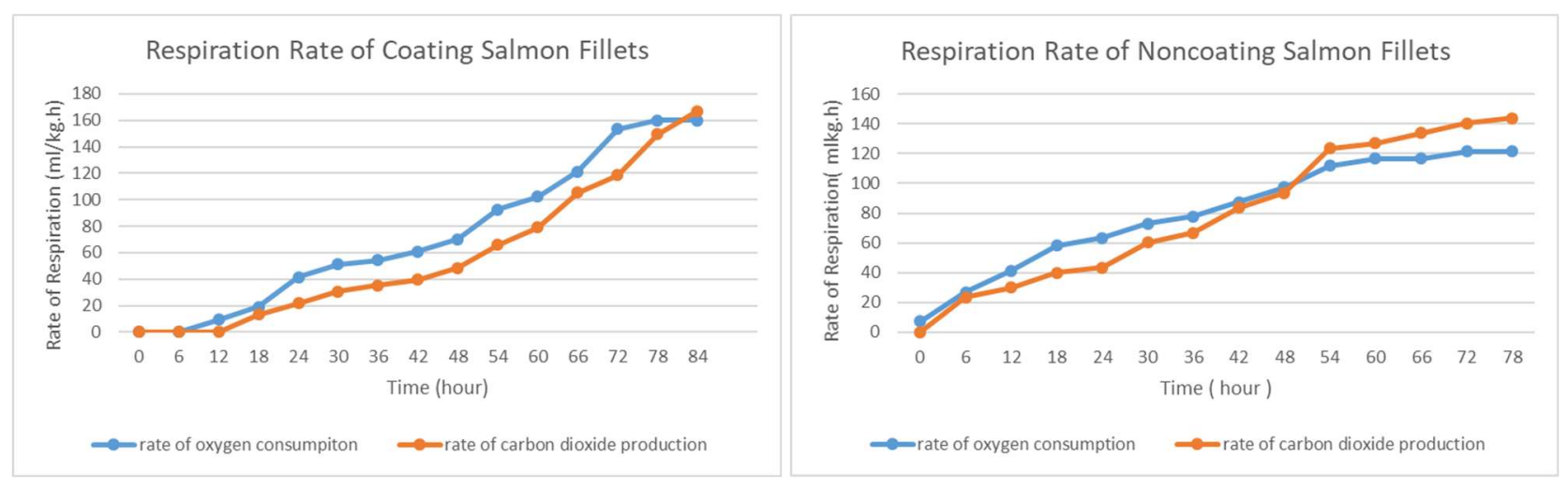

Fig.-2: Respiration Rate of Coating and Non-coating Salmon Fillets

By evaluating the rate of $\mathrm{CO}_{2}$ production and the rate of $\mathrm{O}_{2}$ consumption, it is possible to evaluate the nature of the respiration process. Comparison of the rate of $\mathrm{CO}_{2}$ production to the rate of $\mathrm{O}_{2}$ consumption is called Respiratory Quotient (RQ). RQ is useful for deducing the nature of the substrate in respiration, how long the reaction has taken place, and the process is aerobic or anaerobic. ${ }^{16}$

\section{FT- IR Analysis}

The FT-IR has been used to study the interaction between fused biofilm and antimicrobial agents attached to it. Fig.-3 shows the FT-IR spectrum of CT, ASS, CTASS film, and biodegradation of CTASS film. Absorption in area $3387.0 \mathrm{~cm}^{-1}$ shows (- $\mathrm{OH}$ group from chitosan and carbohydrates and $-\mathrm{NH}_{2}$ from chitosan), $2931.0 \mathrm{~cm}^{-1}$ (C - H stretching, $\mathrm{sp}^{3}$ ), $1581.63 \mathrm{~cm}^{-1}$ (showing COO- carbonyl groups). The peak which absorbed at $1651.07 \mathrm{~cm}^{-1}$ shows the deformation of the N-H group in the ASS and the aldehyde group in the $\mathrm{C} 1$ atom of the polymer chain. This can be compared with the FT-IR spectrum of ASS, which shows the wideband at wave number $3425.58 \mathrm{~cm}^{-1}$ that indicates a hydrogen bond is formed with the hydroxyl group of ASS. In addition, absorption peaks at $2924.09 \mathrm{~cm}^{-1}$ exhibits the stretching of $\mathrm{C}-\mathrm{H}$ and around $1064.71-1149.57 \mathrm{~cm}^{-1}$ show the stretching of $\mathrm{C}-\mathrm{O}$ in $\mathrm{C}-\mathrm{O}-\mathrm{H}$ bonds and at 1026 and 871.82 $\mathrm{cm}^{-1}$ region shows $\mathrm{C}-\mathrm{O}$ in the $\mathrm{C}-\mathrm{O}-\mathrm{C}$ bond, and at wave number $1651.07 \mathrm{~cm}^{-1}$ shows the deformation of the $\mathrm{N}-\mathrm{H}$ stretching and the presence of the aldehyde group on $\mathrm{C} 1$ atoms from the end polymer chain. The absorption peak at $3425 \mathrm{~cm}^{-1}$ moves to a smaller extent at $3387 \mathrm{~cm}^{-1}$ indicating an increase in 
intermolecular hydrogen bonds between CT and ASS. From the FT-IR spectrum of CTASS can be seen that there is no addition of new functional groups to the composite film since the interaction is undergone not reaction. Biodegradation of the film shows absorption at $3749.62 \mathrm{~cm}^{-1}$ and $3425 \mathrm{~cm}^{-1}$ (presence of $-\mathrm{OH}$ group), $2924.09 \mathrm{~cm}^{-1}$ (C-H stretching, sp ${ }^{3}$ ), absorption peaks at $1797-1951 \mathrm{~cm}^{-1}$ indicating the presence of carbonyl groups (aldehyde) caused by the influence of enzymatic hydrolysis by fungi and $1627 \mathrm{~cm}^{-1}$ showing deformation of the amine group. Peaks at 1080.14 and $871.82 \mathrm{~cm}^{-1}$ show $\mathrm{C}-\mathrm{O}$ in $\mathrm{C}-\mathrm{O}-\mathrm{C}$ bonds.

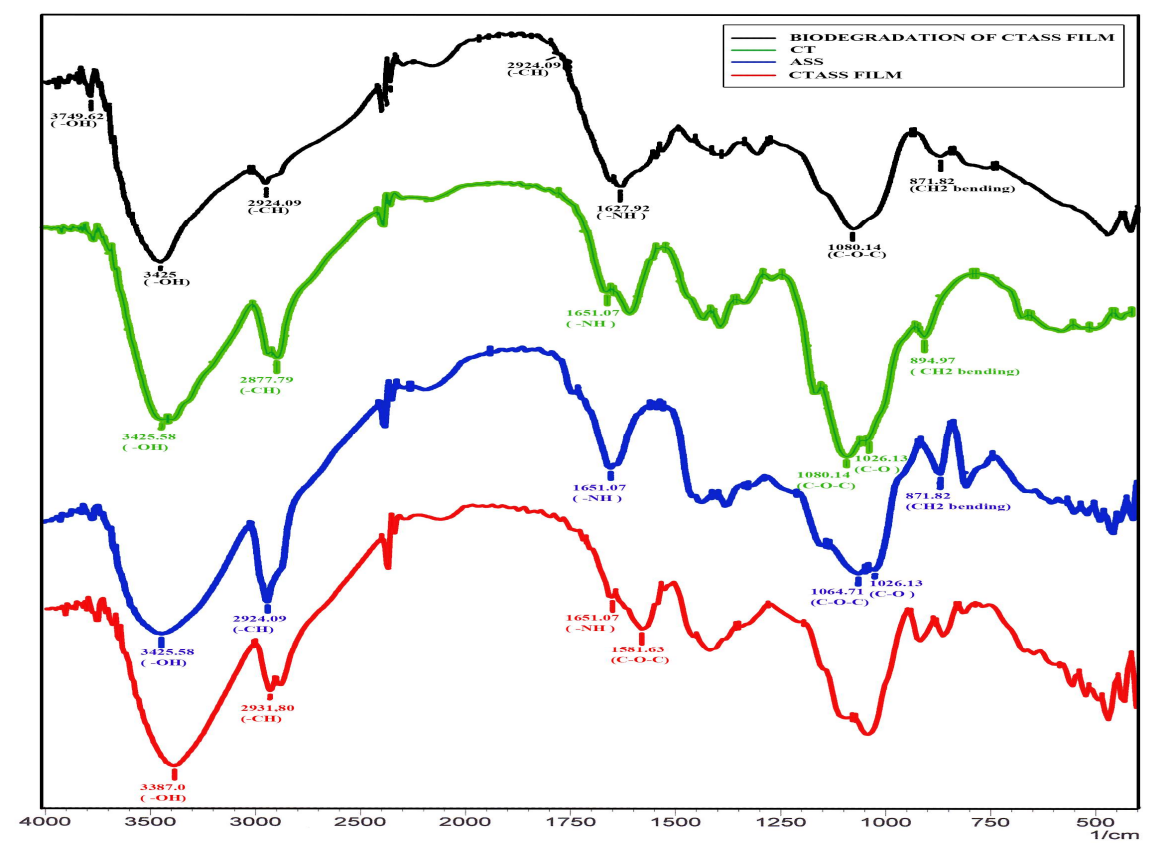

\section{Morphology Analysis}

Fig.-3: FT-IR Spectra of CT, ASS, CTASS Film and Biodegradation of CTASS Film

SEM analysis shows the morphology of the sample. Principally, if there is a change in material such as faults, curvature, and changes in structure from the surface, the material tends to experience energy changes. Changed energy can be emitted, reflected, absorbed, and transformed into electron wave functions that can be captured and read the results. Fig.-4 shows the morphology of the surface and cross-section of CTASS film. Magnification of the film showed the surface of the edible film was homogenous and smooth and the cross-section of the film also indicated a smooth and homogenous appearance based on 2000x and $5000 \mathrm{x}$ magnification. The smooth surface might be developed from the composition of galactomannan in ASS and the decent casting method when the film was made.

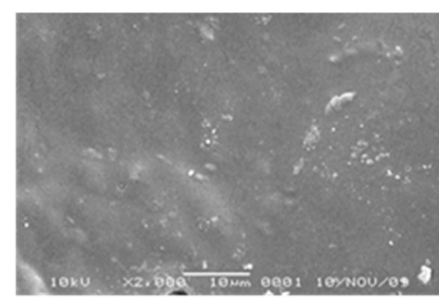

(a)

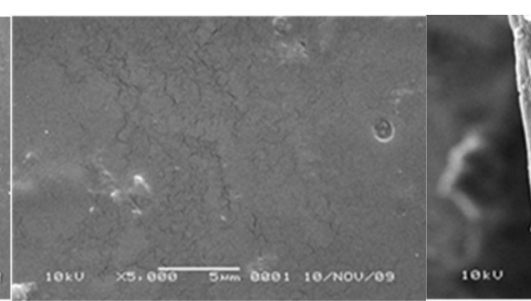

(b)

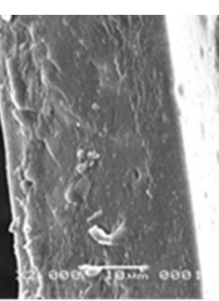

(c)

Fig.-4: SEM Photographs of (a) Surface of CTASS film $2000 \mathrm{x}$ magnification (b) Surface of CTASS $5000 \mathrm{x}$ magnification and (c) Cross-section of Chitosan - aren Seed Starch Film 2000 x magnification

The morphology of CTASS film after biodegradation for 21 days can be shown in Fig.-5. From the SEM photographs, it indicated that the film might be degraded after biodegradation with Aspergillus niger, the film structure was damaged due to the bioactivity of fungi to destroy the biopolymer film. Another 
indication that the film had black spots that significantly could not be rinsed and there was some weight loss of the CTASS films after 21 days biodegradation.

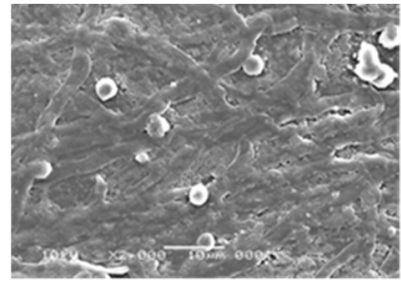

(a)

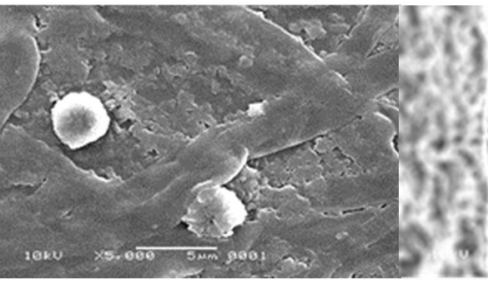

(b)

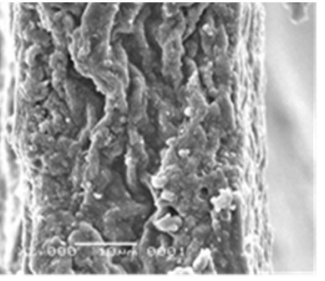

(c)

Fig.-5: SEM Photographs after Biodegradation for 21 Days of (a) Surface of CTASS Film $2000 \mathrm{x}$ magnification (b) Surface of CTASS Film 5000 x magnification and (c) Cross-section of CTASS Film 2000 x magnification

\section{Inhibition Zones of CTASS Film}

Inhibition zones of CTASS film were evaluated in a Kirby-Bauer test. The disk diffusion assay performs a broader clear zone for gram-positive bacteria (Staphylococcus aureus). In Contrast, a less clear zone was observed for gram-negative bacteria (Escherichia coli, Shigella, Salmonella and Pseudomonas aeruginosa, respectively). The antimicrobial index of coating films containing microbial cultures can be viewed in Table-2.

Table-2: Inhibition Zones of CTASS Films Against 5 Pathogen Bacteria

\begin{tabular}{c|c}
\hline Bacteria & Index \\
\hline Escherichia coli & 2.615 \\
\hline Staphylococcus aureus & 2.931 \\
\hline Shigella sp & 0.585 \\
\hline Salmonella sp & 0.731 \\
\hline Pseudomonas aeruginosa & 0.638 \\
\hline
\end{tabular}

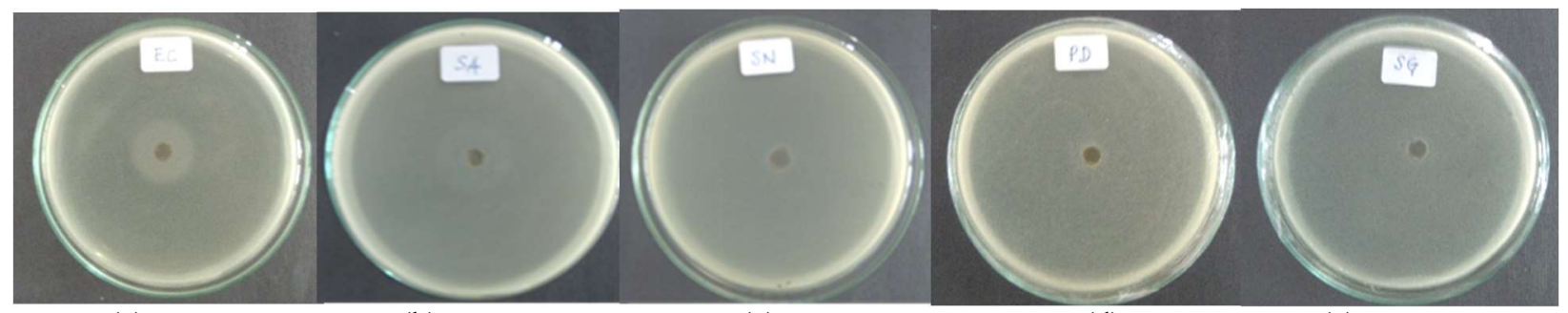

(a)

(b)

(c)

(d)

(e)

Fig.-6: Zone of Inhibition Study of CTASS Film against (a) EC (Escherichia coli), (b) SA (Staphylococcus aureus), (c) SN (Salmonella), (d) PD (Pseudomonas aeruginosa) and (e) SG (Shigella).

From this study, it is found that Staphylococcus aureus which is gram-positive bacteria has a greater index than gram-negative bacteria. This is due to gram-positive bacterial cell contain $1-4 \%$ of lipid which is quite low and consist of a single layer of peptidoglycan, also these bacteria do not have an external membrane that might accommodate antimicrobial agents penetrate to the cell wall. On the other hand, gram-negative bacteria have a higher content of lipid (11-12\%) and consist of many layers of polymers and it causes antimicrobial agents to have limitations to penetrate the cell wall. This indicates gram-positive bacteria have higher sensitivity towards antimicrobial agents. ${ }^{24}$

\section{Salmon Fillets Coating Assay}

Figure-7 shows the total count of psychrophilic and mesophilic bacteria calculated from uncoated assay and coating assay. It is found that CTASS film that coated on salmon fillets developed a lower population of several bacteria present in comparison to non-coating sample during storage for 20 days $(0,1,2,3,5,10,15$ and 20 days) at $5-10^{\circ} \mathrm{C}$. This is due to the blending film which contains chitosan on salmon tissue can increase the effectiveness against microorganisms. The effectiveness of chitosan against microorganisms is 
due to its performance as a preservative to reduce the spoilage of fish muscles. Chitosan can interact with starch- forming a complex that can affect the activity of antimicrobia ${ }^{25}$. From this study, evaluation of total bacteria increasing during the escalation of the storage time. Thus, the effectiveness of coating is decreased. It can be proved significantly by increasing the total count of bacteria during storage. Based on Indonesian National Standard, Fish Fillets that are secure for eating are around $1 \times 10^{5}$ organism/g during storage at 5 $-10^{\circ} \mathrm{C}$. This study evaluated that on the fifth day, the quality of salmon fillets that are coating with CTASS edible film is still safe for consumption. The protective action of chitosan-starch film that applied to salmon fishes had been reported by Vascones et $\mathrm{al}^{12}$ that indicate a reduction of a total of mesophilic and psychrophilic bacteria. Other authors also reported decaying of fruit and vegetables against Candida lambica were reduced when chitosan coating was applied. ${ }^{26}$

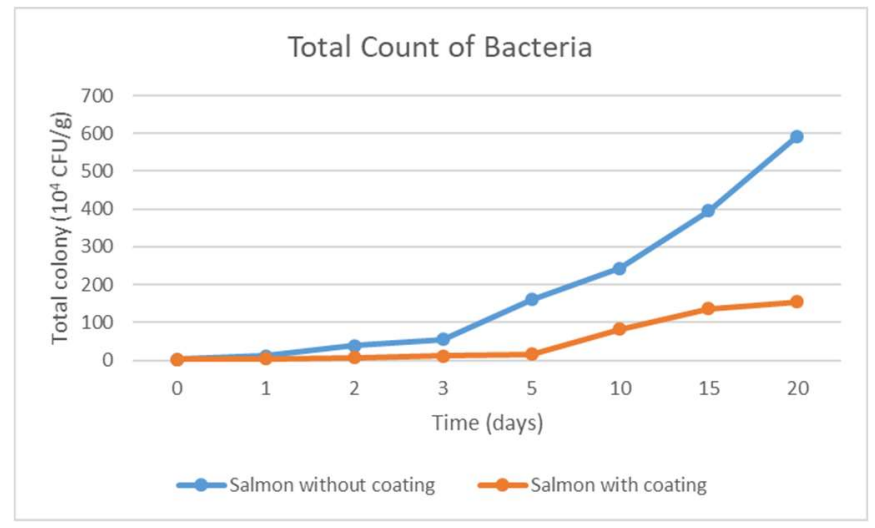

Fig.-7: Surface Count of Total Bacteria (mesophilic and psychrophilic) during storage

\section{CONCLUSION}

The current investigation shows that the smooth surface of film from SEM analysis, the value of water activity of the film was still below the threshold of microbial growth therefore it is suitable for food packaging. $\mathrm{O}_{2}$ and $\mathrm{CO}_{2}$ gas respiration rate at $10^{\circ} \mathrm{C}$ showed that CTASS film can reduce $\mathrm{O}_{2}$ gas concentration and increase $\mathrm{CO}_{2}$ gas concentration that indicated it can prolong the shelf-life of fresh salmon fillets. The characterization from FT-IR indicated that vigorous intermolecular hydrogen bonds occur between CT and CTASS film. WVP of the blended film revealed that CTASS films were not too effective to hold moisture due to the high polarity of the films and required further investigation. The antimicrobial activity studied by agar diffusion assay revealed the antagonist effect using 5 pathogenic microorganisms that indicated the presence of interaction between the amine group of chitosan binding to starch on the blended films. The salmon fillet coating assay performed that salmon fillet wrapped by film matrix was still safe for consumption at $5^{0}-10^{\circ} \mathrm{C}$ through Indonesia National Standard for food packaging. Biodegradation of CTASS film using Aspergilus niger as an indicator showed the weight loss that indicated the decomposition of the edible film. Therefore, these blended films could be recommended as seafood coating materials.

\section{ACKNOWLEDGEMENT}

We acknowledge the financial support from Mrs. NG A HAN. The authors are grateful for Mr. Tulus Joseph Marpaung, Prof. Dr. Jamaran Kaban, M.Sc, Dr. Mimping Ginting, MS and Laboratory of Food Packaging Industrial Ministry in Jakarta, Organic Chemistry Laboratory, Universitas Sumatera Utara, Food Science Laboratory, Universitas Sumatera Utara and Organic Chemistry Laboratory, Universitas Gajah Mada, Yogyakarta.

\section{REFERENCES}

1. F.M. Fakhouri, S.M. Martilli, T. Caon, and J. I. Velasco, Postharvest Biology and Technology, 109, 57 (2015), https://doi.org/10.1016/j.postharvbio.2015.05.015

2. G. Li, J. Huang, T. Chen, T. Wang, H. Zhang, and Q. Chen, Carbohydrate Polymer, 176, 75(2017), https://doi.org/10.1016/j.carbpol.2017.08.068 
RASĀYAN J. Chem.

Vol. 14 | No. 3 |1860-1868| July - September | 2021

3. Z. Ma, A.G. Maestu, and K.C. Jeong, Carbohydrate Polymer, 176, 257(2017), https://doi.org/10.1016/j.carbpol.2017.08.082

4. V. Jost, K. Kobsik, M. Schmid, and K. Noller, Carbohydrate Polymer,110, 309(2014), https://doi.org/10.1016/j.carbpol.2014.03.096

5. T. H. McHugh, Macromolecular Interactions in Food Technology, 650, 134(1996), https://doi.org/10.1021/bk-1996-0650

6. C.N. Cutter, Meat Science, 74, 131(2006), https://doi.org/10.1016/j.meatsci.2006.04.023

7. K. Hyene, Sago. De uttige planten van Indonesie, (3e ed.). Netherlands/Indonesia: Van Hoeve, S. Gravenhage/Bandung, p.330-339(1950).

8. M.R. Ishaka, S.M. Sapuana, Z. Lemana, M.Z.A. Rahmand, U.M.K. Anwar, and J.P. Siregar, Carbohydrate Polymer, 91, 699(2013), http://dx.doi.org/10.1016/j.carbpol.2012.07.073

9. C. Bangyekan, D.A. Ong, and K. Srikulkit, Carbohydrate Polymers, 63, 61(2006), https://doi.org/10.1016/j.carbpol.2005.07.032

10. K.I. Sallam, Food Control, 18, 566(2007), https://doi.org/10.1016/j.foodcont.2006.02.002

11. J.G. Estaca, P. Montero, B. Giménez, and M.C.G. Guillén. Food Chemistry, 105, 511(2007), https://doi.org/10.1016/j.foodchem.2007.04.006

12. M.B. Vásconez, S.K. Flores, C.A. Campos, J. Alvarado, and L.N. Gerschenson, Food Research International, 42, 762(2009), https://doi.org/10.1016/j.foodres.2009.02.026

13. V. Mahdavi, S.E. Hosseini, and A. Sharifan, Wiley Food Science and Nutrition, 6, 269(2017), https://doi.org/10.1002/fsn3.544

14. T.P. Labuza, L.N. Kreisman, C.A. Heinz, and P. P. Lewicki, Journal of Food Processing and Preservation, 1, 31(1977), https://doi.org/10.1111/j.1745-4549.1977.tb00311.x

15. ASTM, Standard Test Methods for Tensile Properties of Thin Plastic Sheeting, D882-91. Annual book of ASTM. Philadelphia, (1996).

16. E. Julianti, Master Thesis, Department of Food Science, IPB, Bogor (1997).

17. S.A. Nurwantoro and A.S. Djarijah, Mikrobiologi Pangan Hewani, Kanisius, Yogyakarta, Indonesia, (1997).

18. K. Yamada, H. Takahashi, and A. Noguchi, International Journal of Food Science and Technology, 30, 599(1995), https://doi.org/10.1111/j.1365-2621.1995.tb01408.x

19. G.G. Buonocore, A. Conte, and M. A. Del Nobile, Journal of Food Science, 70(2), 142(2005), https://doi.org/10.1111/j.1365-2621.2005.tb07087.x

20. C.M. Noronha, S.M. Carvalho, R.C. Lino, and P.L. Barreto, Food Chemistry,159, 529(2014), https://doi.org/10.1016/j.foodchem.2014.02.159

21. C. Amni, Ismet, S. Aprilia, M. Mariana, and S. A. Akbar, Rasayan Journal of Chemistry, 13(1), 275(2020), http://dx.doi.org/10.31788/RJC.2020.1315492

22. K. Vaezi, G. Asadpour, and H. Sharifi, International Journal of Biological Macromolecules, 124, 519(2019), https://doi.org/10.1016/j.ijbiomac.2018.11.142

23.X. Huang, F. Xie, and X. Xiong, Carbohydrate Polymers, 201, 367(2018), https://doi.org/10.1016/j.carbpol.2018.08.085

24. F.K. Siregar, D.Y. Nasution, Y. Muis, and D.Y. Kaban, Rasayan Journal of Chemistry, 12(2), 554(2019), http://dx.doi.org/10.31788/RJC.2019.1225126

25. F. Devlieghere, A. Vermeulen, and J. Debevere, Food Microbiology, 21, 703-714(2004), https://doi.org/10.1016/i.fm.2004.02.008

26. M.H. Ofman, C.A. Campos, and L.N Gerschenson, Lebensmittel Wissenschaft und Technologie, 37(3), 355-361(2004), https://doi.org/10.1016/j.lwt.2003.09.010

[RJC-6158/2020] 